\title{
MULTIMEDIA MUSIC MAP: SUPPORT OF TEACHING FOR PRIMARY ART SCHOOLS
}

\section{Aleš VÁVRA, Helena KILIANOVÁ, Jiří SEDONÍK}

\begin{abstract}
The paper describes creation and using of multimedia music map of the Czech Republic. The final output is meant as an addition for teaching and learning of music theory at primary art schools. The map is created in electronic form as an online solution and is freely accessible for everyone. The map content corresponds with the requirements of teachers at primary art schools. The main theme of the map is music, which contains the selected places, coupled with the most famous Czech composers and Czech music festivals. The map contains several multimedia components, like a audio, video, images, texts, etc. This interactive web map is created in the Google Maps API V3, interactivity is extended through modern technologies - AJAX, XML, jQuery library with lots of plugins and other additions.
\end{abstract}

Key words: music map, multimedia map, primary art school.

\section{MULTIMEDIÁLNÍ HUDEBNÍ MAPA: PODPORA VÝUKY NA ZÁKLADNÍCH UMĚLECKÝCH ŠKOLÁCH}

Resumé: Článek popisuje tvorbu a využití multimediální mapu ČR na téma hudba. Mapa obsahuje vybraná místa spojená s nejvýznamnějšími českými hudebními skladateli a nejvýznamnějšími českými hudebními festivaly. Výsledná mapa je určena $\mathrm{k}$ doplnění výuky hudební nauky na základních uměleckých školách. Jedná se o interaktivní webovou mapu vytvořenou v prostředí Google Maps API V3 obsahující několik multimediálních prvků jako audio, video, obrázky, texty apod. Interaktivita mapy je rozšiřrena prostřednictvím moderních technologií - AJAX, XML, knihovny jQuery s velkým množstvím pluginů a dalších.

Klíčová slova: hudební mapa, multimediální mapa, základní umělecká škola

\section{1 Úvod}

Cílem projektu je vytvořit multimediální mapu ČR na téma hudba, která má obsahovat vybraná místa, spojená $\mathrm{s}$ nejvýznamnějšími českými hudebními skladateli a nejvýznamnějšími českými hudebními festivaly.

Výsledná mapa je určena $\mathrm{k}$ doplnění výuky hudební nauky na základních uměleckých školách. Mapa by se mohla stát zdrojem komplexnějších informací o hudebních skladatelích či hudebních festivalech, dále by mohla napomoci $\mathrm{k}$ těsnějšímu propojení osobnosti či události s danou lokalitou a přispět tak k rozšsiření znalostí „hudebního místopisu“ ČR. Výsledná podoba mapy respektuje požadavky základních uměleckých škol. Podle osnov hudební nauky základních uměleckých škol je také přizpůsoben tematický obsah mapy. Mapa obsahuje multimediální prvky zejména zvukové (audio) ukázky, video ukázky, texty, obrázky apod.

\section{Použité technologie}

Pro tvorbu mapy byl použit značkovací jazyk HTML a kaskádové styly CSS. Tématická data jsou skladována $\mathrm{v}$ databázi MySQL, se kterou webové prostředí komunikuje prostřednictvím PHP skriptů. Využitím API rozhraní společnosti Google Maps byly dále používány jazyky a technologie AJAX, XML a Javascript, pomocí kterých byly naprogramovány veškeré funkční prvky mapy.

(X)HTML. Značkovací jazyk HTML (Hypertext Markup Language) se používá pro tvorbu WWW stránek. Dříve se také používal pro formátování vzhledu, avšak $\mathrm{s}$ nástupem kaskádových stylů bylo od tohoto způsobu využití upuštěno (1). Zápis $\mathrm{v}$ tomto jazyce je jednoduchý. Č́sti textu podle jejich významu jsou uzavírány do značek neboli tagů. Na základě HTML vznikl jazyk XHTML (Extensible Hypertext Markup Language), který je do jisté míry považován za nástupce HTML, a navíc splňuje pravidla daná pro formát XML (2). Při tvorbě hudební mapy byla dodržena specifikace 
konsorcia W3C pro XHTML 1.0 ve verzi Transitional.

CSS. Kaskádové styly neboli CSS (Cascading Style Sheets) je jazyk navržený konsorciem W3C pro formátování dokumentu napsaného v jazycích HTML, XHTML nebo XML. S jeho pomocí lze definovat např. velikost a typ písma, barvy a dokonce i umístění elementů, a tím oddělit vzhled dokumentu od jeho struktury a obsahu. Jak již z názvu jazyka vyplývá, jednotlivé definice stylů lze na sebe vrstvit, avšak platí pravidlo platnosti poslední definované vrstvy. Nadefinovaná pravidla lze zapsat do jediného externího CSS souboru, na který se v HTML stačí pouze odkázat (3). Přri tvorbě hudební mapy byla dodržena specifikace konsorcia W3C pro CSS 2.1.

PHP. Jedná se o programovací jazyk vyvinutý pro potřeby tvorby dynamických webových stránek. PHP (Hypertext Preprocessor) je jazykem serverovým, tzn., že pracuje na straně serveru. Webový server s PHP obdrží ze strany klienta http požadavek a zpátky uživateli je pak zaslán pouze výsledek. Výhodou jazyka PHP je tedy nulové zatížení klientského počítače při vykonávání skriptu a také jeho nezávislost na platformě. Lze jej navíc interpretovat přímo v HTML kódu. PHP je vhodně používán pro práci s daty, proto byl ve verzi 5.3 při sestavení mapy využit pro komunikaci s databází MySQL. Kombinace těchto dvou technologií je v současné době velmi populární při tvorbě různých webových aplikací, také je hojně využívána na mnoha webových serverech, které poskytují webhosting zdarma (4).

MySQL. MySQL je relačním databázovým systémem, který je k dispozici jako open source, tedy je šíren zdarma a s otevřeným kódem. Jedná se $\mathrm{o}$ jednu $\mathrm{z}$ nejrozšířenějších nekomerčních databází, která se ve většině př́ípadů používá v kombinaci s programovacím jazykem PHP. K dalším výhodám MySQL (My Structured Query Language) patří podpora všech hlavních platforem a její uživatelská vstřícnost a jednoduchost. $Z$ názvu databáze vyplývá, že je založena na jazyce SQL (Structured Query Language). Jazyk SQL patří mezi deklarativní programovací jazyky, což znamená, že kód jazyka SQL se nepíše v samostatném programu, ale vkládá se do jiného programovacího jazyka, který je již procedurální (5).

JavaScript. Patří do skupiny programovacích jazyků používaných při tvorbě internetových stránek, jež se také často vkládá přímo do HTML kódu stránky. Patř́i do skupiny klientských jazyků, jejichž kód psaný v JavaScriptu se spouští až po odeslání stránky ze serveru na klienta (do prohlížeče), kde je následně skript vykonán. Vznikl v důsledku potřeby vytvářet dynamické internetové stránky $\mathrm{z}$ méně populárních statických. Jeho nevýhodou mohou být časté chyby $\mathrm{v}$ důsledku různých verzí jazyka či prohlížečù, neschopnost přistupovat k souborům a také možnost jeho snadného zakázání uživateli v nastavení prohlížeče (6).

Shadowbox. Je jeden $\mathrm{z}$ mnoha webových prohlížečů různých formátů fotografií, který však podporuje i formáty dalších medií jako např. videa. Je napsán v JavaScriptu a v CSS, který je snadno přizpůsobitelný (7).

Google Maps API V3. Společnost Google poskytuje bezplatnou službu Google Maps API, která vývojářum umožňuje do svých webových stránek vložit vlastní data nad mapové podklady poskytované touto společností. Jedná se o sbírku funkcí a procedur vytvořenou $\mathrm{v}$ jazyku JavaScript, kterou může autor stránek využít pro programování mapové aplikace. Nejnovější verze API je navržena tak, aby se mapový podklad načital rychleji, zejména pak na mobilních zařízeních (8).

Infobox. InfoBox je skript rozšiřující možnosti API prostředí o zobrazení informačního okna u objektu v mapě. Chová se podobně jako okno google.maps.InfoWindow definované v dokumentaci API, avšak podporuje možnost pokročilého stylování vzhledu okna pomocí CSS. Díky této vlastnosti jej lze také využívat jako statický popisek objektu v mapě (9).

MarkerClusterer. Tato javascriptová knihovna seskupuje znaky, jenž se $\mathrm{v}$ daném měřítku přes sebe překrývájí, a vytváŕí nad nimi symbol pro shluk znaků (tzv. Cluster). Podstatou skriptu je seskupení znaků do skupin v závislosti na jejich vzdálenosti od středu Clusteru, kterou si programátor stanoví. Počet znaků, které byly do Clusteru seskupeny, se zobrazí uprostřed symbolu pro Cluster. Při změně měřítka mapového pole (tzn. při přiblížení či oddálení), se vytvořený Cluster zruší a pro aktuální měřítko se znaky znovu seskupí do nových Clusterů (10).

jQuery. Jedná se o javascriptovou knihovnu, která klade dưraz na interakci mezi JavaScriptem a HTML. Velkou výhodou tohoto frameworku je způsob, kterým dokáže zjednodušit, zefektivnit a zrychlit tvorbu webu či webových aplikací. Navíc má podrobně zpracovanou dokumentaci a velké množství dostupných pluginů, které dále rozšiřují jeho funkcionalitu. S knihovnou jQuery lze měnit vzhled či obsah stránky, přidávat efekty 
a animace, či pomocí technologie AJAX získávat informace ze serveru bez nutnosti načtení celé stránky (11).

Tablesorter. Jedná se o jQuery plugin, pomocí kterého lze řadit záznamy různých datových typů podle libovolného sloupce tabulky bez znovunačtení stránky. Dokáže seřadit texty, čísla, data, časy, měny, internetové adresy, IP adresy a další. Navíc podporuje atribut colspan (i rowspan), který byl využit při generování levého postranního panelu (12).

jScrollPane a jScrollHorizontalPane. Těmito pluginy je umožněno nahradit $\mathrm{v}$ prohlížečích výchozí svislé a vodorovné posuvníky na všech blocích, které mají CSS stylem nastavenou vlastnost overflow na hodnotu auto. Požadovaný vzhled je možné si nadefinovat pomocí CSS Společně $\mathrm{s}$ těmito pluginy se využivá plugin jquery.mousewheel.js, pomocí kterého je umožněno pohybovat se nejen posuvníkem šipkami, ale také kolečkem myši $(13,14)$.

jGrowl. Je plugin pro zobrazování zpráv v prohlížeči. Díky němu lze zobrazit např́ílad varovné či informační zprávy v okně, které lze vzhledově a pozičně přizpůsobit opět pomocí stylopisu CSS (15).

AJAX. AJAX (Asynchronous JavaScript and XML) je označení pro technologii, která umožňuje komunikaci prohlížeče s webovým serverem, aniž by docházelo ke znovu načitáni stránky při změně obsahu stránek. Vznik této technologie má za následek vývoj velkého množství interaktivních webových aplikací. Výměna dat se provádí objektem XMLHttpRequest, nebo pomocí technologie Remote Scripting v prohližžčích, které XMLHttpRequest nepodporují. S technologií AJAX se lze nejčastěji setkat u ,portálových našeptávačưu, které podle prvních písmen okamžitě nabízejí nejhledanější výrazy, či u mapových portálů (Google Maps, Mapy.cz, Amapy.cz a další), které díky této technice dynamicky načítají obrázek mapy (16).

$X M L$. Je dalším jazykem $\mathrm{z}$ dílny konsorcia W3C, který je především určen pro výměnu dat mezi aplikacemi a pro dokumenty, u nichž nezáleží na jejich vzhledu, avšak na obsahu jednotlivých částí. Je-li to nutné, lze styl XML dokumentů definovat kaskádovými styly. Stejně jako jazyk HTML používá tagy, jejichž názvy však nejsou přesně specifikovány. Je používán jako otevřený formát, jehož podpora může být snadno implementována do mnoha aplikací, což je velký rozdíl oproti různým vlastním firemním formátům. Výhodou je jeho snadná možnost úprav $\mathrm{v}$ jednoduchých textových editorech či konverze do jiných formátů. Je alternativou $\mathrm{k}$ formátu JSON (17).

\section{Postup zpracování}

\subsection{Vytvoření emailového dotazníku}

$\mathrm{Na}$ začátku práce byl základním uměleckým školám zaslán emailový dotazník, který měl definitivně rozhodnout o podobě, obsahu a použité technologii při tvorbě hudební mapy. Z důvodu neexistující databáze emailových adres všech Základních uměleckých škol nemohl být email zaslán hromadně. Bylo proto z celkového počtu 460 škol náhodně vybráno 200 škol, kterým byl emailový dotazník zaslán.

Kontakty na vybrané školy byly získány bud' z rejstříků škol Ministerstva školství, mládeže a tělovýchovy (18) z portálu Umělecká škola (19) a z vlastních internetových stránek základních uměleckých škol.

$\mathrm{V}$ úvodu rozeslaného emailu bylo shrnuto téma a cíle projektu. Poté byly zástupcům uměleckým škol položeny následující otázky. První nejdůležitější otázka se týkala využitelnosti této práce při výuce hudební nauky. Zda by hudební mapa s multimediálními prvky mohla přispět $\mathrm{k}$ zatraktivnění výuky. Následně navazoval dotaz týkající se technického řešení mapy. Zda by školy uvítaly mapu př́stupnou přes internet, čímž by byla zajištěna její lepší dostupnost, nebo by raději přivítaly mapu poskytovanou na $C D$. Další otázka směřovala $\mathrm{k}$ technickému vybavení. Jestli je škola vybavena počítačovou učebnou či třídou s učitelským počítačem napojeným na dataprojektor. Součástí tohoto bloku bylo i zjištění, zda škola při výuce využívá internet. Pro správné naplnění tematického obsahu byly ještě školy dotázány na literaturu, učebnice a osnovy, podle kterých se hudební nauka realizuje. Závěrem měli zástupci škol možnost přidat své nápady, postřehy, pozitivní či negativní názory.

\subsection{Zpracování emailového dotazníku}

Z celkového počtu 200 oslovených odpovědělo na zaslaný dotazník 30 škol. Ve všech odpovědích bylo téma hudební mapy, která by byla vhodná pro výuku hudební nauky, považováno za výborný nápad a za využitelnou alternativu pro zpestření výuky.

Navíc bylo ve všech odpovědích uvedeno, že řešení mapy dostupné přes internet je vhodnější než distribuování mapy na $\mathrm{CD}$, které by bylo jistě velkým problémem. Toto řešení bylo podpořeno i čtyřmi školami, které prozatím požadovanou 
techniku nevlastní, avšak se na pořízení základní techniky v blízké době chystají. Zbytek škol potřebnou technikou disponuje. Je tedy zřejmě, že pokud školy vlastní počítač či počítačovou učebnu, je jejich součástí vždy př́stup $\mathrm{k}$ internetu.

Z učebních materiálů se na většině škol použivají pracovní sešity Martina Vozara a Hany Šípkové (20) či vtipně zpracovaná učebnice Dagmar Lisé (21).

$\mathrm{Na}$ základě výsledků tohoto dotazníku byly obsah a zejména forma mapy přizpůsobeny požadavkům základních uměleckých škol. Pro sestavení obsahu mapy byly tedy použity osnovy, učebnice a další literatura používaná základními uměleckými školami při výuce hudební nauky. Podle výsledků dotazníku bylo dále rozhodnuto, že zvolenou formou hudební mapy bude mapa, poskytovaná pomocí webových technologií, a pro solidní technickou vybavenost učeben $\mathrm{s}$ připojením $\mathrm{k}$ internetu nebude tedy nutné vytvářet mapu na $\mathrm{CD}$.

\subsection{Zpracování tematického obsahu}

Prvním krokem při zpracování tematického obsahu byl výběr hudebních skladatelů, festivalů a s nimi spojených významných lokalit. Následovalo začlenění multimediálních prvků jako audio a video ukázek, fotografií a životopisů hudebních skladatelů, charakteristik a log festivalů a fotografie míst.

$\mathrm{Na}$ základě výsledků dotazníku bylo rozhodnuto, že hudební mapa bude vytvořena pouze ve webovém prostředí. V úvahu tedy přicházelo využití technologie libovolného mapserveru, nebo technologie vybraného API pomocí mapových portálů. $Z$ důvodu možnosti využití mapových rastrových podkladových

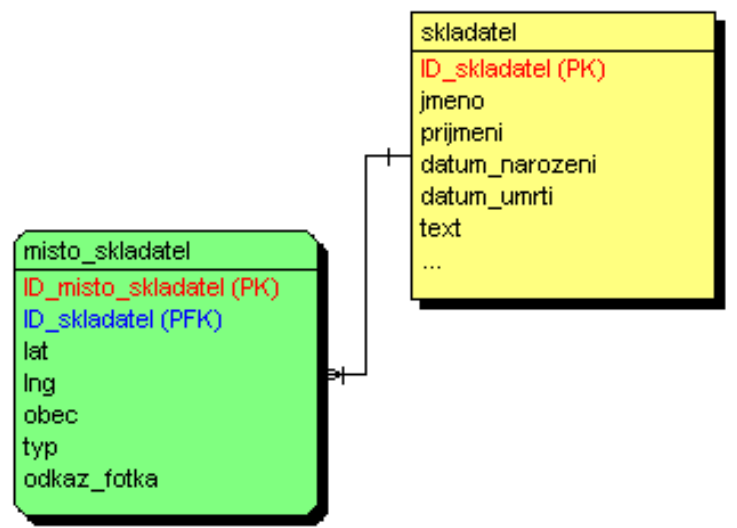

přesnější topologické informace o bodovém objektu, bylo po prozkoumání poskytovaných služeb API mapových portálů vybráno prostředí Google Maps API V3.

Dále byla nastavena úroveň tematického obsahu a základní funkcionalita multimediální hudební mapy. Samotné technické provedení, volba barev, intuitivnost funkcí pro ovládání mapy bylo navrženo hlavně s ohledem na uživatelskou prŕijemnost. Pro inspiraci sloužily různé internetové stránky určené pro podobné spektrum uživatelů, na nichž se hodnotilo např́íklad jejich technické provedení či provedení barevného vzhledu webové mapy.

Dále se při řešení technických problémů hojně využívalo internetových diskuzí a dostupných manuálů. Kmenovým manuálem byly oficiální stránky Google Maps API ve verzi 3 (8), kde se nachází popis většiny funkcí $\mathrm{s}$ př́klady jejich využití, či diskuze vývojářu tohoto API (22).

\subsection{Struktura databáze a webové mapy}

Hlavními dvěma tabulkami v databázi jsou tabulky skladatel a festival. Tabulka skladatel obsahuje mimo jiné základní atributy jako jmeno, prijmeni, datum_narozeni či datum_umrti, také atribut text $\mathrm{s}$ životopisem, dále pole, která obsahují cestu $\mathrm{k}$ adresářům $\mathrm{s}$ fotkami, playlisty mp3 přehrávače či odkaz na video, umístěné na internetovém serveru YouTube. Obdobně tabulka festival obsahuje kromě atributů nazev, rok zalozeni, také atribut text $\mathrm{s}$ charakteristikou festivalu, pole $\mathrm{s}$ cestou $\mathrm{k}$ adresáŕi s logy festivalů a pole www s odkazem na oficiální stránky hudebních festivalů.

Ke každé $\mathrm{z}$ těchto dvou tabulek byly $\mathrm{v}$ relaci $1: \mathrm{N}$ vytvořeny tabulky misto_skladatel, respektive misto_festival. Obě tyto tabulky mají

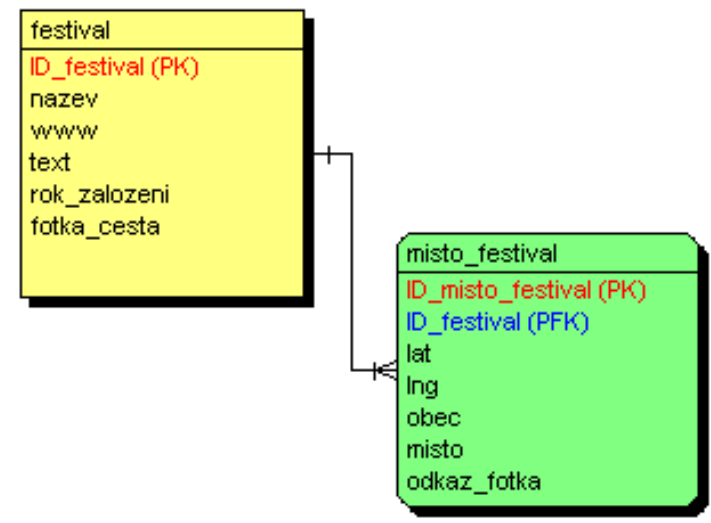

Obr 1: Schéma struktury uloženi tabulek v databázi

vrstev, kdy zejména hybridní podklady jsou $\mathrm{v}$ úrovni velkých měřítek vhodné pro podání mimo jiné společné atributy lat a lng datového typu float $\{10,6\}$ v nichž je uložena informace 
o poloze daného místa a atribut ID skladatel (v př́padě tabulky misto_festival atribut ID_festival), který je cizím klíčem z tabulky skladatel (festival).

Všechny tabulky $\mathrm{v}$ databázi jsou kódovány v utf8_czech_ci a mají svůj primární klíč (ID_nazev_tabulky) datového typu integer s funkcí auto increment, která každému novému záznamu přidá vlastní ID vyšší o jedna. Veškerá správa databáze probíhala pomocí webového rozhraní nástroje phpMyAdmin.

$\mathrm{Z}$ důvodu tvorby mapy pro výukové účely není součástí výsledné webové mapy aplikační prostředí, jímž by byla registrovaným uživatelům dána možnost podílet se na doplňování tematického obsahu respektive přidávání objektů do mapy. Všem uživatelům je tedy umožněno pouze prohlížení mapy, multimediálních prvků a dalších zobrazených informací.

\subsection{Tvorba webové mapy}

Výsledná tvorba mapy byla rozdělena do několika dílčích krokủ. Po výběru vhodného softwaru byla nejprve naprogramována základní API mapová aplikace, ve které byl kladen důraz na propojení mapy s hotovou databází, z níž byly generovány bodové objekty do mapového pole. Záznamy jsou $\mathrm{z}$ databáze generovány pomocí PHP skriptu, který vytvoří XML soubor, jenž je následně zpracován technologií AJAX, a vygenerované body jsou načteny do mapy.

Dále zde byl zvolen vhodný typ ovládacích prvků (zoom a panel pro přepínání mapových podkladů) a bylo umístěno měrítko. Byla nastavena základní úroveň zoomu a střed zobrazovaného území, které podle zadání práce $\mathrm{v}$ mapovém poli vykreslovaly území České republiky. $Z$ tohoto důvodu byla také znepřístupněna možnost oddálení se za úroveň základního zoomu.

Následovalo sestavení znakového klíče mapy, pro kterou byl použit symbol ze sbírky mapových ikon od Google Maps ze sady Culture \& Entertainment (23). Vybranému znaku byla z důvodu rozdělení hudebních skladatelů podle hudebního směru upravena barva pozadí pomocí programu Corel. V tomto programu byl dále vytvořen znak pro festivaly, jenž vychází z tvaru symbolu pro hudební skladatele. Symbol, který nahradí seskupené znaky, byl z hlediska vhodného oblého tvaru použit $\mathrm{z}$ dokumentace skriptu MarkerClusterer (24). Tento symbol byl v legendě nazván jako „Překryv znakư““.

Dalším krokem bylo rozšíření funkcionality pro zatraktivnění mapy. Pomocí PHP skriptu byl z databáze vygenerován levý postranní panel se seznamem hudebních skladatelů a festivalů, $\mathrm{k}$ nimž jsou pririrazena místa $\mathrm{s}$ nimi spjatá, která jsou propojena $\mathrm{s}$ body $\mathrm{v}$ mapě. Vygenerované položky $\mathrm{v}$ panelu se při najetí myší zbarví podle barvy př́slušného znaku v legendě. Kliknutím na položku $\mathrm{v}$ levém postranním panelu se informační panel v pravé části, který byl doposud naplněn úvodním odstavcem $\mathrm{s}$ návodem $\mathrm{k}$ používání mapy a $\mathrm{s}$ řešením problémů, naplní pomocí dalšího PHP skriptu a AJAXu životopisem a dalšími údaji $\mathrm{z}$ databáze o vybraném skladateli či festivalu. Obdobným způsobem se také naplní záložky $\mathrm{v}$ panelu multimédií - odkazem na video a přehrávačem mp3 ukázek s př́slušným playlistem skladeb. Ve spodní části webové mapy se nachází legenda $\mathrm{s}$ formulářem, kterým je možné $\mathrm{z}$ mapového pole přidat či odebrat festivaly a prríslušné skladatele vybraného hudebního směru.

Vlastní JavaScript $\mathrm{s}$ definovanými funkcemi je uložen v hlavičce dokumentu index.php. Tímto skriptem je obsluhována veškerá činnost mezi vygenerovanými panely, legendou a mapou. Pomocí tohoto skriptu dochází $\mathrm{k}$ definování ikon použitých $\mathrm{v}$ mapě a následné načtení mapy s vygenerovanými body. Dále byly definovány funkce, jimiž lze přibližit lokalitu vybranou $\mathrm{z}$ levého či pravého postranního panelu.

Většina ostatních funkcí vychází z javascriptové knihovny jQuery a jejích pluginů. Za pomocí této knihovny byly vytvořeny záložky v panelu Multimedia a seznamy lokalit, které se animovaně zobrazí při výběru skladatele nebo festivalu v levém panelu. Pomocí pluginu Tablesorter jsou v levém postranním panelu skladatelů řazeny položky podle jména či data narození (obdobně u festivalů podle názvu či roku založení) vzestupně nebo sestupně. V seznamu hudebních skladatelů jsou položky uvedeny ve formátu ,jméno, př́ijmení“. Při řazení podle jména jsou skladatelé seřazení podle př́ijmení. Pluginy jScrollPane ajScrollHorizontalPane spolu s externím CSS souborem jScrollPane.css byly použity k nastylování horizontálních a vertikálních posuvníků postranních panelů a legendy. Pluginem jGrowl je $\mathrm{v}$ prohlížeči vyvolána informační zpráva $\mathrm{v}$ př́ípadě, když si uživatel vybere lokalitu, jejíž symbol je $\mathrm{v}$ legendě vypnutý.

Další použitým skriptem je markerclusterer.js, jenž seskupuje všechny znaky, které se $\mathrm{v}$ daném měřítku přes sebe překrývají. Pro zobrazování informačních oken $\mathrm{u}$ bodů $\mathrm{v}$ mapě byl použit 
skript infobox.js. Po kliknutí na vybrané místo hudebního skladatele se informační okno naplní př́slušným názvem lokality, jménem a př́ijmením autora a fotografíi lokality (obdobně se dějiště festivalu doplní celým názvem lokality, názvem festivalu a fotografií lokality). Pro prohlížení fotografií míst a videí byl použit prohlížeč medií Shadowbox, definovaný skriptem shadowbox.js a stylopisem shadowbox.css.

Souběžně $\mathrm{s}$ rozšiřováním funkcionality byl vytvářen vzhled stránky pomocí kaskádových stylů CSS a HTML. Vzhled byl optimalizován pro rozlišení 1280x800 a vyšší. V nižších rozlišeních dochází ke zmenšení mapového pole, nebot' postranní panely mají nastavenou pevnou šiřku. Funkcionalita webové mapy byla optimalizována pro prohlížeče Mozilla Firefox 3.6, Opera 10.5 a Google Chrome 4.1. jenž vede ke zatraktivnění mnohdy značně stereotypního předmětu.

Aby byla mapa školami ve výuce použivána, bylo nutné správně zpracovat tematický obsah mapy, který primárně vycházel $\mathrm{z}$ osnov a literatury používané na školách. Mezi nejdůležitější části zpracovávaného obsahu patří multimediální prvky, a to zejména prvky zvukové (audio), prrípadně video, či prvky obrázkové a textové.

Webová mapa dále obsahuje úvodní pokyny, jak s mapou pracovat či pár rad a tipů, jak řešit prípadné problémy. V sekci Problémy je taky možné nahlédnout či si stáhnout obrázek s ideálním načtením mapy $\mathrm{v}$ prohlížeči (nebere se v úvahu rozložení stránky, které závisí na rozlišení monitoru uživatele, avšak pouze funkcionalita všech částí stránky, která může být

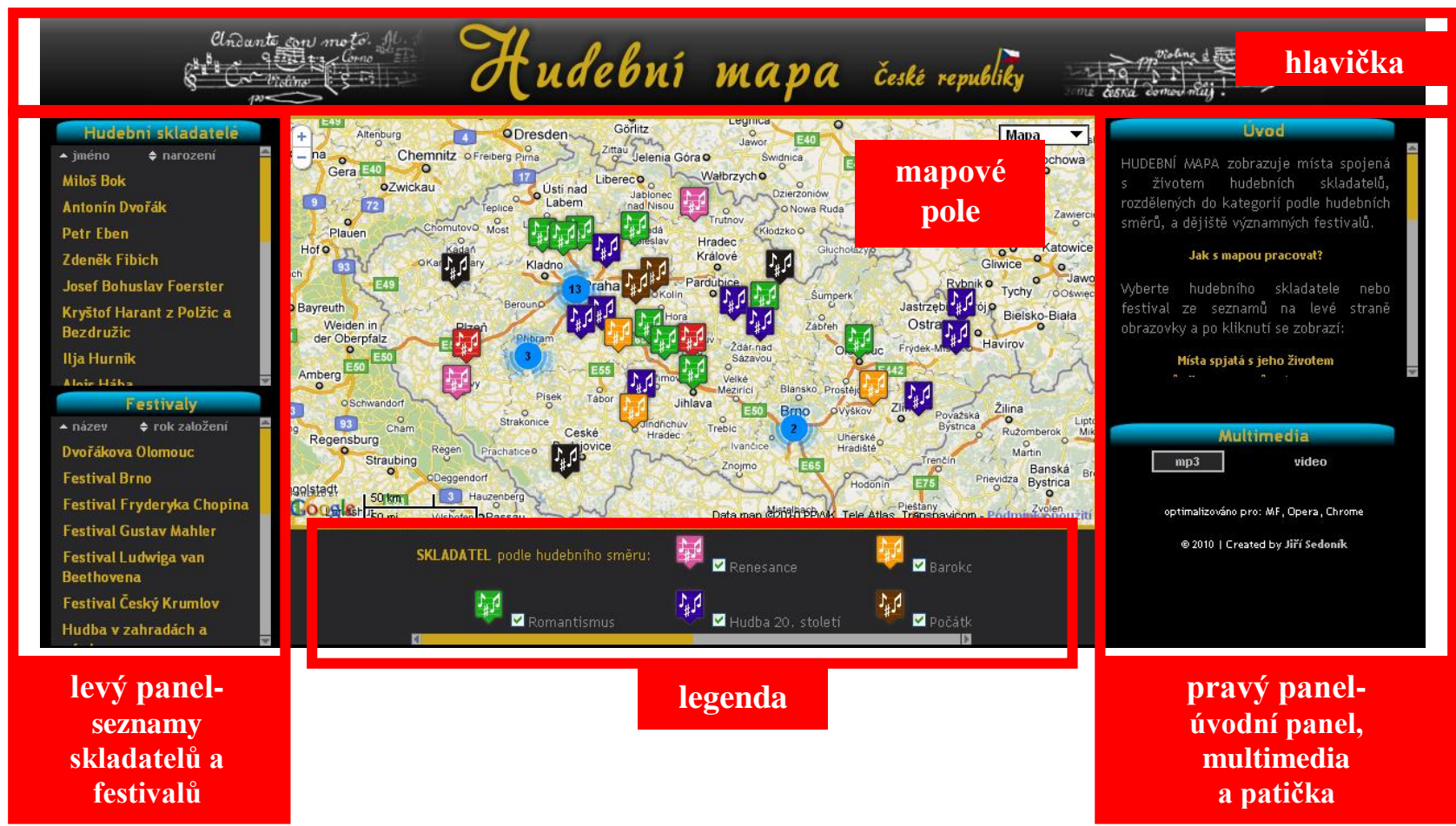

Obr 2: Ukázka kompozice a umistěni funkčnich prvků v mapě

\section{Výsledky}

Multimediální hudební mapa ČR je umístěna na adrese http://gislib.upol.cz/app/sedonik10/.

Webová mapa je založena na volně dostupném API prostředí portálu Google Maps a integrované databázi MySQL. Mapa je určena pro potřeby výuky předmětu hudební nauka na základních uměleckých školách. Zobrazuje významná místa spojená s českými hudebními skladateli a festivaly, kteří jsou součástí osnov tohoto předmětu. Mapa je vhodným doplňkem, narušena např. nepovolením JavaScriptu v prohlížeči, nenainstalováním Adobe Flash Player minimálně verze 7 apod.).

\section{Závěr}

Cílem projektu bylo vytvořit multimediální mapu ČR na téma hudba. Mapa je určena $\mathrm{k}$ doplnění výuky hudební nauky na základních uměleckých školách. Obsahuje vybraná místa, spojená s nejvýznamnějšími českými hudebními skladateli a nejvýznamnějšími českými hudebními festivaly. Její součástí jsou také 
multimediální prvky zejména zvukové (audio) ukázky, video ukázky, texty, obrázky apod.

Výsledná mapa byla vytvořena podle požadavků základních uměleckých škol, které byly obeslány emailovým dotazníkem. Z výsledku dotazníku vyplynulo technické řešení mapy. Podle učebnic, osnov hudební nauky a další literatury uveřejněných $\mathrm{v}$ odpovědích na dotazník, byl také přizpůsoben tematický obsah mapy.

Webová mapa je založena na volně dostupném API prostředí portálu Google Maps a integrované databázi MySQL. Ke komunikaci $\mathrm{s}$ databází a $\mathrm{k}$ rozšíření funkcionality hudební mapy byly použity jazyky PHP, AJAX, XML, JavaScript.

Výsledná mapa bude v budoucnu propagována na webových stránkách cílové uživatelské skupiny a má potenciál stát se vhodným doplňkem pro výuku hudební teorie na základních uměleckých školách.

\section{Literatura}

[1] JANOVSKÝ, D.: Jak psát web: o údržbě a zlepšování internetových stránek [online]. 1996, 2013-03-31 [cit. 2013-04-02]. Dostupné z: http://www.jakpsatweb.cz/

[2] W3C XHTML2 Working Group Home Page [online]. 1995-2007, 2013-02-21 [cit. 2013-0331]. Dostupné z: http://www.w3.org/MarkUp/

[3] SCHAFER, S.: HTML, XHTML a CSS: bible pro tvorbu $W W W$ stránek. 1. vyd., Praha: Grada, 2009. ISBN 978-80-247-2850-6

[4] PONKRÁC, M.: PHP a MySQL bez predchozich znalostí: prưvodce pro samouky. 1. vyd., Brno: Computer Press, 2007. ISBN 978-80251-1758-3.

[5] Databáze a jazyk SQL. Interval.cz [online]. 2000-08-04, [cit. 2013-02-11]. Dostupné z: http://interval.cz/clanky/databaze-a-jazyk-sql/ [6] FLANAGAN, D.: JavaScript: kompletni průvodce. Praha: Computer Press, 2002. ISBN 80-7226-626-8.

[7] Shadowbox.js [online]. 2007-2010, [cit. 201302-10]. Dostupné z:

http://www.shadowbox-js.com/

[8] Google Developers. V3: The Solution for Maps Applications for both the Desktop and Mobile [online]. 2012, 2012-07-27 [cit. 2013-0211]. Dostupné z:

http://code.google.com/intl/cs/apis/maps/docume documen/v3/

[9] Google-maps-utility-library-v3. InfoBox v1.1.12 [December 11, 2012] Reference [online]. 2012 [cit. 2013-02-11]. Dostupné z: http://google-maps-utility-libraryv3.googlecode.com/svn/trunk/infobox/docs/refer ence.html.

[10] Google-maps-utility-library-v3.

MarkerClusterer [online]. 2012 [cit. 2013-02-

02]. Dostupné z: http://google-maps-utility-

libraryv3.googlecode.com/svn/trunk/markerclust erer/docs/reference.html

[11] MELČÁK, J.: jQuery: Tahák v podobě PDF. Profimagazin [online]. 2011, 2008-10-06 [cit. 2013-02-02]. Dostupné z:

http://www.profimagazin.cz/jquery/jquery-tahakv-podobe-pdf

[12] BACH, C.: jQuery plugin: Tablesorter 2.0 [online]. [cit. 2013-02-11]. Dostupné z:

http://tablesorter.com/docs/

[13] jScrollHorizontalPane.

jScrollHorizontalPane | jQuery Plugins [online]. 2010, 2008-04-15, [cit. 2010-05-04].

Dostupné z:

http://plugins.jquery.com/project/jscrollhorizonta lpane

[14] JScrollPane [online]. [cit. 2013-02-02].

Dostupné z:

http://www.kelvinluck.com/assets/jquery/jScrollP ane/jScrollPane.html

[15] LEMON, S.: jGrowl 1.2.11. Stanlemon.net [online]. 2013, 2013-03-16 [cit. 2013-04-05].

Dostupné z:

http://stanlemon.net/projects/jgrowl.html

[16] SNÍŽEK, M.: AJAX - kde jsou hranice? Snizekweb.cz [online]. 2005-2013, 2005-09-13 [cit. 2013-02-21]. Dostupné z:

http://www.snizekweb.cz/clanky/ajax-kde-jsouhranice/

[17] Extensible Markup Language (XML). [online]. 2012-41-01,[cit. 2013-02-03]. Dostupné z: http://www.w3.org/XML/

[18] MŠMT. Rejstřík škol [online]. [cit. 2012-0711]. Dostupné z: http://rejskol.msmt.cz/

[19] Základni umélecké školy seznam uméleckých škol [online]. [cit. 2012-07-13]. Dostupné z: http://www.umelecka-skola.cz/

[20] Š́́PKOVÁ, H. a VOZAR, M.: Hudebni nauka pro ZUŠ: pracovni sešit pro 1-5. ročník. Talacko Editions, 2005.

[21] LISÁ, D.: Hudební nauka pro malé i větši muzikanty 1 a 2. 3. vyd., Praha: Editio Bärenreiter, 2003.

[22] Google Maps API V2 [online]. 2013 [cit. 2013-02-11]. Dostupné z: http://groups.google.com/group/Google-

Maps-API/topics 
[23] Map Icons Collection | Google

Maps Icons, Map Markers, Free POI Icons, GIS

Symbols [online]. 2013 [cit. 2013-02-11].

Dostupné z:

Mgr. Aleš Vávra

icons/

http://code.google.com/p/google-maps-

[24] MarkerClusterer v1.0 Reference [online]. 2013 [cit. 2013-02-04]. Dostupné z: http://gmaps-utility-

library.googlecode.com/svn/trunk/markerclustere r/1.0/docs/reference.html\#MarkerClusterer

Katedra geoinformatiky

Přírodovědecká fakulta UP

17. listopadu 50

77140 Olomouc, ČR

Tel: +420 585634525 ,

E-mail: ales.vavra@upol.cz

Www pracoviště: www.geoinformatics.upol.cz 